\title{
PERFORMANCE OF DIFFERENT DRYING METHODS AND THEIR EFFECTS ON THE PHYSIOLOGICAL QUALITY OF GRAIN SORGHUM SEEDS (S. bicolor (L.) Moench) $)^{1}$
}

\author{
LUCIA BRANDÃO FRANKE², MIGUEL ÂNGELO PEIXOTO TORRES ${ }^{3}$, RODRIGO RAMOS LOPES ${ }^{4}$
}

\begin{abstract}
This experiment viewed to evaluate the physiological quality of grain sorghum seeds as well as to determine the respective drying curve of each of three drying methods. The seeds harvested at $18.9 \%, 18.1 \%$, and $18.2 \%$ of moisture content were submitted to the following drying methods : a) under natural conditions, b) an intermittent dryer in which the combustion of firewood was the source of caloric energy, and c) a stationary dryer in which the source of caloric energy was the burning of liquefied petroleum gas. The experimental design was a completely randomized one with 25 repetitions of one hundred seeds each. The water contents and weight of one thousand seeds were evaluated. Seeds physiological quality was evaluated by germination and vigor tests. Seed drying rates were of $0.11,1.25$, and 0.55 percent points per hour $\left(\mathrm{pph}^{-1}\right)$ for the natural, intermittent and stationary drying methods, respectively. The intermittent treatment permits the highest loss of water in the shortest period of time, and germination and vigor remaining unchanged.
\end{abstract}

Index terms: natural drying, artificial dryer, drying speed, germination, vigor.

\section{DESEMPENHO DE DIFERENTES MÉTODOS DE SECAGEM E SEUS EFEITOS SOBRE A QUALIDADE FISIOLÓGICA DE SEMENTES DE SORGO GRANÍFERO} (S. bicolor (L.) Moench)

\begin{abstract}
RESUMO - O objetivo deste trabalho foi verificar a qualidade fisiológica das sementes de sorgo granífero e determinar a curva de secagem em função da utilização de diferentes métodos de secagem. As sementes com teor de água inicial de $18,9 \%, 18,1 \%$ e $18,2 \%$ foram secas até $12,6 \%, 12,3 \%$ e $12,9 \%$, respectivamente, em eira sob secagem natural, secador intermitente equipado com fornalha de combustão à lenha e secador estacionário com fundo falso perfurado equipado com queimador a gás liquefeito de petróleo (GLP). O delineamento experimental utilizado foi o completamente casualizado com 25 repetições de 100 sementes. O teor de água e o peso de mil sementes foram determinados e a qualidade fisiológica foi avaliada por testes de germinação e vigor. A velocidade média obtida nas secagens natural, intermitente e estacionária foi de $0,11,1,25$ e 0,55 pontos percentuais por hora $(\mathrm{pp} / \mathrm{h})$, respectivamente. $\mathrm{O}$ tratamento com secador intermitente possibilita a maior perda de água em um menor espaço de tempo, e sementes com maior poder germinativo e vigor.
\end{abstract}

Termos para indexação: secagem natural; secagem artificial, velocidade de secagem, germinação, vigor.

${ }^{1}$ Submetido em: 24/07/2008. Aceito para publicação em: 03/09/2008.

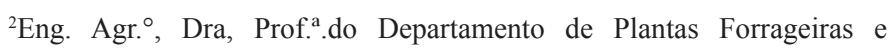
Agrometeorologia, Faculdade de Agronomia/UFRGS, Cx. Postal: 15.100, CEP: 91501-970, Porto Alegre /RS, lbfranke@ufrgs.br

${ }^{3}$ Eng. Agr ${ }^{\circ}$, MSc., UFRGS, Porto Alegre/RS, Bolsista CAPES, patymitorres@yahoo.com.br

${ }^{4}$ Eng. Agr., MSc., Doutorando do curso de Pós-graduação em Zootecnia, Faculdade de Agronomia, Universidade Federal do Rio Grande Sul, Bolsista CNPq, e-mail: lopezhsf@hotmail.com 


\section{INTRODUCTION}

Sorghum (Sorghum bicolor (L) Moench) is a very important crop worldwide, and today is the fifth most cultivated cereal in the world (EMBRAPA, 2005). In Brazil, sorghum was re-introduced in 1970, specially in western zones of the South region. Sorghum areas were then expanded, from the mid 1990's onwards, as an alternative to soybean. The repercussion was so significant that the demand for regular seed volumes stimulated producers, industry and researchers to work together in search for new hybrids (CONAB, 2004).

Sorghum grains should be harvested when moisture content is between 18 and $20 \%$. Seeds within this moisture range have to be dried in order to reduce moisture contents to values between 12 and $13 \%$, since high moisture contents are the main reason behind losses in germination and vigor, (Mantovani, 2003). Natural or artificial drying methods may be chosen, depending on characteristics of each species, the amount of harvested seeds, and on weather conditions prevailing after seeds were harvested.

Natural seed drying is directly dependent on weather conditions. The disadvantage of the method lies in the need for intensive human labor, which in turn leads to poor operational performance. Nevertheless, whether conducted directly under de sun or in the shade, natural drying is very important in seed production, as it brings about consistent, homogeneous post-harvest seed maturation (Berti et al., 2005).

Artificial drying methods are more often used, and are more easily adaptable to seed production techniques, affording fast and efficient removal of large amounts of moisture (Carvalho, 1994). Mechanical drying techniques may be used with the assistance of mechanical, electric or electronic equipment, in which air is forced through the seed mass. These methods afford the maintenance of seed quality, when conducted under technical criteria that define exposure times and temperatures (Ahrens et al., 2000). According to Cavarini et al. (1998), the main advantages of the artificial method are to allow the control of the temperature, the drying air flux, and the exposure time of the seeds to the heated air, fundamental factors to assure the efficiency of the process.

Several factors have to be considered when choosing between seed drying methods. These aspects include seed volumes effectively harvested, harvest speed, drying time, energy consumption, end purpose of seeds, apart from human-related aspects like technological knowledge and purchase power of the producer. Nevertheless, the specific characteristics of each product harvested as seen in the light of the heat transfer technique adopted may determine the best drying method to be used, with minimal damage to physical and physiological seed quality (Maia, 1995).

This study aimed to evaluate the performance of some seed drying methods in terms of physiological quality of grain sorghum seeds.

\section{MATERIAL AND METHODS}

Grain sorghum seeds (cultivar DKB 599, Dekalb), were provided by São Domingos Seed Commerce. Seeds were produced in the Lagoão district, municipality of Pantano Grande, state of Rio Grande do Sul (RS), Brazil, at 126 $\mathrm{km}$ from Porto Alegre. The experiment comprised three drying treatments: a) drying under natural conditions, b) an intermittent dryer whose source of caloric energy was firewood, and c) a stationary dryer provided with a perforated bottom in which the source of caloric energy was petroleum liquefied gas.

In the natural drying method, sorghum seeds were harvested on $03 / 17 / 2005$ and transported to the Agrometeorological and Forage Crops Department of the Federal University of Rio Grande do Sul (UFRGS). The drying procedure started on the next day and lasted 7 days $(56 \mathrm{~h})$. Seed mass weight was $300 \mathrm{~kg}$, with $18.9 \%$ baseline moisture content. Seeds were initially sieved in a $4 \mathrm{~mm}$ mesh screen and subsequently spread as five piles of $60 \mathrm{~kg}$ each, with $10 \mathrm{~cm}$ thick layers spaced at $0.5 \mathrm{~m}$ intervals under direct sunlight across an $8 \mathrm{~m}^{2}$ concrete floor previously covered with woven propylene bags. Exposure time was $8 \mathrm{~h}$ a day with hourly upturns. Moisture measurements were carried out three times a day (at 9 am, 2 pm, and $5 \mathrm{pm}$ ) using a digital grain moisture meter Multi Grain. The average solar radiation observed during the drying period, measured by the

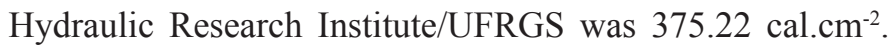
day $^{-1}$. After reaching the final moisture content of $12.6 \%, 25$ $1.5 \mathrm{~kg}$ samples were collected, transferred to paper bags, and sent to the Seed Analysis Laboratory.

In the intermittent drying process, two driers of intermittent and slow seed flow (IMPASA 90) were used. The static capacity of each drier was of $5,400 \mathrm{~kg}$. The static load of the drying chamber (cross-flow, tray type) was of $10,800 \mathrm{~kg}$ of seeds. Seeds were lifted in a $10 \mathrm{~m}$ high grain elevator equipped with scoops and driven by a 2 HP engine. The system was supplied with a firewood combustion furnace and a 2,700 kg wooden bag silo. On 04/01/2005, 10,800 kg seeds with approximate of $18.1 \%$ moisture were harvested and sent to Engenho Moinhos, Pantano Grande, RS, where the seeds were discharged into a hopper and transported by the elevator to an air screen separator to reduce impurities as well as get some reduction in seed moisture content. After that, the seeds were transported to the drier previously adjusted to a $67 \mathrm{~m}^{3} \cdot \mathrm{min}^{-1} \cdot$ ton $^{-1}$ airflow, with initial air 
temperature of $50.3^{\circ} \mathrm{C}$ and maximum temperature of $60.3^{\circ} \mathrm{C}$, and an intermittence ratio of 1:4. Temperature and relative humidity were measured every hour with thermometers (rod and probe). Likewise, grain moisture content was monitored every hour by digital grain moisture meter Multi Grain. When seeds reached the final moisture content of $12.3 \%, 25$ $1.5 \mathrm{~kg}$ samples were collected, transferred to paper bags, and transported to the Seed Analysis Laboratory.

The stationary drying process used two driers models, both equipped with gas burners (Baron - circular; Bandeirante - rectangular), each with a static load of 2,700 $\mathrm{kg}$ and a height of $1.50 \mathrm{~m}$. The assembly operated in the Post Harvest Technology Center of de UFRGS, in the municipality of Eldorado do Sul, RS. On 05/03/2005, 5,400 $\mathrm{kg}$ of sorghum seeds with $18.2 \%$ of moisture were harvested and, in the same day, transported to the driers. Because the drying method was processed from the base to the surface of the seeds, three layers were formed: a layer with dried seeds (a), a transition layer (b), and a layer with humid seeds (c). From each layer samples were collected and brought to the Seed Analysis Laboratory. Temperatures and relative humidities of the seed mass drying air flow were monitored with a digital thermometer Dry Eration, with thermocouples installed in the holes on the sides of the drier and of the plenum. Seed moisture content was measured using the digital grain moisture meter Multi Grain, at 1-h intervals throughout the drying process (Table 4).

Drying rate of seeds was calculated dividing the percentage of water removed from seeds by the hour count of the drying process. Drying curves were determined by adjusting the curve considering the change in seed moisture content and the length of the drying process.

In order to evaluate the physical and physiological quality of the seeds, the following tests were conducted: Moisture content - determined after the initial cleaning using a digital meter Multi Grain Wild in 100-g samples analyzed in triplicate, with results expressed in percentage; Purity test - conducted with 25 samples of each drying method, which were sieved three times and forced through a seed blower for 3 min (De Leo model South Dakota), with an opening set at $6.5 \mathrm{~cm}$; Germination test - carried out over paper as 25 repetitions of 100 seeds each, in square plastic containers (11 x $11 \times 3 \mathrm{~cm}$ ) placed in a germination chamber at a constant temperature of $25^{\circ} \mathrm{C}$, for 10 days. The results were expressed as percentage of normal seedlings (Brazil, 1992); Weight of 1000 seeds - it was determined by weighing 8 samples of 100 seeds retrieved from the mass of pure seeds from the purity analysis, according to Brazil (1992); First count - the record of the percentage of normal seedlings as determined four days after the beginning of the test.

This experiment was set according to a completely random design. The data obtained were statistically analyzed by the Duncan test to compare means, at the $5 \%$ level of probability.

\section{RESULTS AND DISCUSSION}

The moisture content: drying time ratio of sorghum seeds for the three drying methods is represented by a quadratic function. Seed drying occurred at a decreasing ratio, growing slower with time (Figure 1).

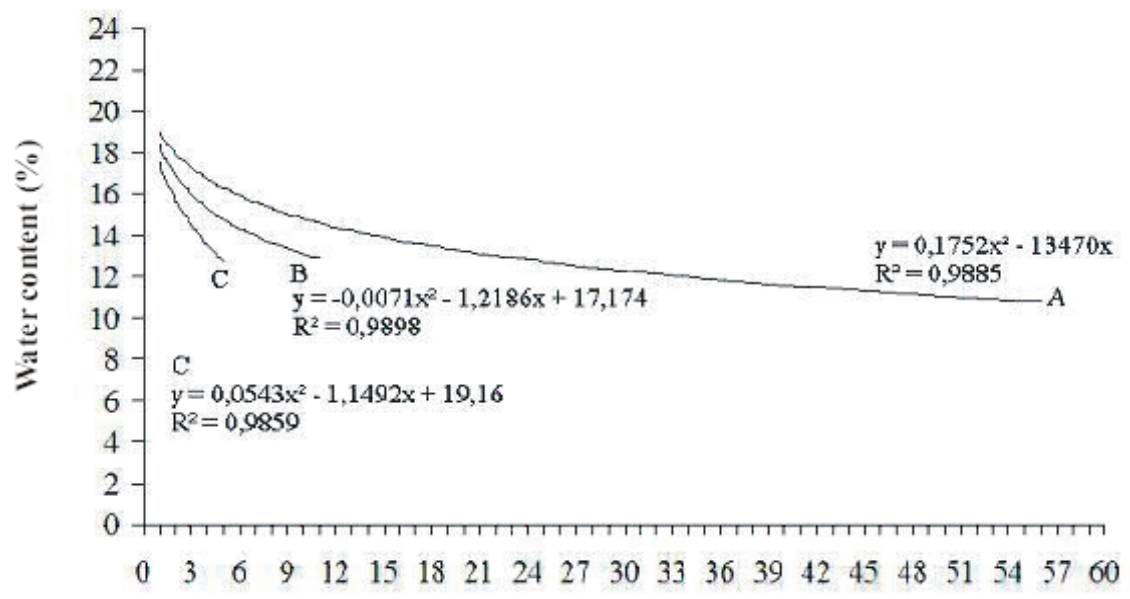

Drying time (hour s)

FIGURE 1. Curves representing moisture contents of grain sorghum seeds in terms of drying time: A) natural drying; B) stationary drying; C) intermittent drying. 
The analysis of the drying curves illustrates that the removal of moisture from seeds was slower in the natural method, and faster in the artificial drying methods (Figure 1). Apart from the method, several other factors added to these differences, such as: exposure times to drying air (heated or not), drying air temperature (high or low), relative humidity in the site (modified or not), drying air flow (natural or forced), and the speed with which moisture migrated from the inner seed structures to its surface. These observations are in accordance with the studies by Teixeira et al. (1980). Yet, Brooker et al. (1981) categorically state that drying depends basically on relative humidity and on airflow.

The natural drying process was slower due to the limitations the method imposes, with $56 \mathrm{~h}$ needed for the seeds to have their moisture reduced from $18.92 \%$ to $12.58 \%$ (7 days, 8h/day) (Figure 1, Table 1). The seeds averaged a loss of approximately $0.11 \mathrm{pph}^{-1}(0.90 \%$ per 8 -h day $)$ (Table 2), with drying speed totally dependent on weather conditions. In this drying treatment, moisture loss observed from the $1^{\text {st }}$ to the $3^{\text {rd }}$ day $(24 \mathrm{~h}, 8 \mathrm{~h} /$ day $)$ was considerable, due to the more favorable weather conditions, but lesser from the $4^{\text {th }}$ to the $7^{\text {th }}$ day $(32 \mathrm{~h}, 8 \mathrm{~h} /$ day $)$. For the first period, mean moisture loss was around $0.20 \mathrm{pph}^{-1}$, and for the second period $0.04 \mathrm{pph}^{-1}$. Generally speaking, temperature varied considerably throughout the day, and also during the whole drying process. The fast initial desorption (up to the $3^{\text {rd }}$ day) only occurred at higher air temperatures $\left(26.6^{\circ} \mathrm{C}\right.$ on the average), $65 \%$ relative humidity, and an airflow speed close to $2.47 \mathrm{~m} \cdot \mathrm{s}^{-1}$. The low drying rate in natural drying process may be harmful to the seeds. Under these drying conditions, microorganisms may develop, as moisture takes longer to be removed, apart from the fact that seeds hold moisture for longer than advisable. Thus, the seed mass temperature may change, with acceleration in respiration which causes a $\mathrm{CO}_{2}$ release and water vapor, besides the consumption of reserves. This may cause a significative decrease in the physiological quality of seeds, although this was not verified in this work (Table 5).

In the intermittent drying method, the time needed to reduce seed moisture from $17.3 \%$ to $12.3 \%$ was of $4 \mathrm{~h}$. This represented a mean moisture loss rate of $1.25 \mathrm{pph}^{-1}$ (Tables 2 and 3). Seeds dried by the intermittent method lost moisture more quickly than the other methods. This result may be explained in the light of the combination of several factors: a) method used; b) shorter exposure time of seeds in the drying chamber and to air flow; c) adjustments in air temperature, in relative humidity, and in air flow; d) synchronicity between exposure time inside the drying chamber and equalization time (1:4); and e) uniformization and dissipation of heat inside the bag silo. The initial drying temperature of $50.3^{\circ} \mathrm{C}$ was adjusted throughout the process, but never surpassed $60.3^{\circ} \mathrm{C}$. The temperature of the seed mass was around $43^{\circ} \mathrm{C}$ (Table 3). The airflow, defined as $67 \mathrm{~m}^{3} \cdot \mathrm{min}^{-1} \cdot$ ton $^{-1}$ for each dryer, was within the limits established by Millmann (2002) (32.84 $\mathrm{m}^{3} \cdot \mathrm{min}^{-1} \cdot \operatorname{ton}^{-1}$ and $72.44 \mathrm{~m}^{3} \cdot \mathrm{min}^{-1} \cdot \operatorname{ton}^{-1}$ ), which is enough to remove moisture from the system. The temperature rise in the drying air diminished relative humidity, and thus increased the capacity of the drying air to remove=seed moisture when the seed mass was exposed to insufflated air (cross-flow), which was subsequently removed from the system, almost saturated with humidity. Intermittent drying allowed to adopt higher air temperatures, as compared to the other methods, without excessively increasing the temperature of seeds due to the equalization period, as observed in our results (Table 3 ). In this treatment, seed upturn greatly influenced drying speed, and was intended to ensure that drying occurred evenly. This made easier the flow of the drying air against the low static pressure, thus increasing drying speed, as verified by the decrease of $1 \mathrm{pp}$ at every turn.

In stationary drying, the time needed to reduce moisture from $18.2 \%$ to $13.2 \%$ was $9 \mathrm{~h}$ (Tables 2 and 4 ). The seed temperature was around $25^{\circ} \mathrm{C}$ (beginning) and moisture content was $18.3 \%$. After $5 \mathrm{~h}$ of drying, the seed mass temperature was $47.1^{\circ} \mathrm{C}$ and seed moisture content was $14 \%$. After this period, the cooling process and the uniformization of moisture content by cross-flowing air was started and after a $4 \mathrm{~h}$ period the seed temperature was $24.2^{\circ} \mathrm{C}$ and moisture content was $13.1 \%$.

The stationary drying method resulted in three different layers, a, b, and c, that is, a layer with dried seeds, a transition layer and a layer with humid seeds, respectively. Drying speed was higher in layer a, due to the fact that seeds were directly exposed for a longer period to the airflow, causing a larger reduction in seeds moisture content. In the other layers (b and c), the seeds final moisture content was higher, requiring longer drying periods. Seed mass temperatures in the layer a and in part of the transition zone were above the recommended values (Table 4). These two layers are located near the air inlet, and thus dry more quickly, showing the fastest desorption rates. Hence the importance of knowing the maximum time span allowed for drying, to prevent temperature from rising above recommended limits. The efficiency of this method depends on the duct architecture, the air flux, and the physical characteristics of the protective cover of the seeds, the volume and architecture of the porous spaces and uniformity of the seed mass (Moraes, 2000). 
TABLE 1. Moisture contents of grain sorghum (\%) at measurement times of the five piles under natural drying.

\begin{tabular}{|c|c|c|c|c|c|c|c|}
\hline \multirow{2}{*}{$\begin{array}{l}\text { Dates } \\
\text { (day) }\end{array}$} & \multirow{2}{*}{$\begin{array}{l}\text { Time } \\
\text { (h) }\end{array}$} & Pile 1 & Pile 2 & Pile 3 & Pile 4 & Pile 5 & Mean \\
\hline & & \multicolumn{6}{|c|}{$(\%)$} \\
\hline Means & & 17,55 & 19,93 & 19,79 & 18,82 & 18,51 & 18,92 \\
\hline \multirow[t]{3}{*}{$18 / 03 / 05$} & 09 & 16,70 & 17,48 & 18,99 & 17,90 & 16,85 & \\
\hline & 14 & 16,64 & 17,32 & 18,76 & 17,50 & 16,66 & \\
\hline & 17 & 16,00 & 17,27 & 18,12 & 17,41 & 16,65 & \\
\hline Means & & 16,44 & 17,35 & 18,62 & 17,60 & 16,72 & 17,34 \\
\hline \multirow[t]{3}{*}{$19 / 03 / 05$} & 09 & 14,04 & 16,00 & 16,60 & 15,71 & 15,89 & \\
\hline & 14 & 13,67 & 15,90 & 16,20 & 15,29 & 15,72 & \\
\hline & 17 & 13,27 & 15,86 & 15,90 & 15,00 & 15,34 & \\
\hline Means & & 13,66 & 15,92 & 16,23 & 15,33 & 15,65 & 15,35 \\
\hline \multirow[t]{3}{*}{ 20/03/05 } & 09 & 13,01 & 15,59 & 15,67 & 15,64 & 14,34 & \\
\hline & 14 & 12,67 & 15,33 & 14,83 & 14,40 & 13,97 & \\
\hline & 17 & 11,30 & 12,12 & 14,05 & 13,26 & 13,78 & \\
\hline Means & & 12,32 & 14,34 & 14,85 & 14,43 & 14,03 & 13,99 \\
\hline \multirow[t]{3}{*}{$21 / 03 / 05$} & 09 & 12,12 & 15,41 & 14,58 & 14,51 & 13,88 & \\
\hline & 14 & 12,04 & 14,03 & 14,10 & 14,10 & 13,60 & \\
\hline & 17 & 12,29 & 12,01 & 13,35 & 13,52 & 13,50 & \\
\hline Means & & 12,15 & 13,81 & 14,01 & 14,04 & 13,66 & 13,53 \\
\hline \multirow[t]{3}{*}{$22 / 03 / 05$} & 09 & 12,41 & 13,96 & 14,65 & 13,71 & 13,50 & \\
\hline & 14 & 11,82 & 13,85 & 14,08 & 13,53 & 13,41 & \\
\hline & 17 & 11,62 & 12,42 & 13,21 & 13,50 & 13,20 & \\
\hline Means s & & 11,95 & 13,41 & 13,98 & 13,58 & 13,37 & 13,25 \\
\hline \multirow[t]{3}{*}{$23 / 03 / 05$} & 09 & 12,49 & 13,71 & 14,23 & 13,30 & 13,20 & \\
\hline & 14 & 11,50 & 12,84 & 13,50 & 13,20 & 13,01 & \\
\hline & 17 & 11,35 & 12,36 & 13,01 & 13,10 & 13,00 & \\
\hline Means & & 11,78 & 12,97 & 13,58 & 13,20 & 13,07 & 12,92 \\
\hline \multirow[t]{3}{*}{$23 / 03 / 05$} & 09 & 12,30 & 13,16 & 13,26 & 13,12 & 12,84 & \\
\hline & 14 & 11,50 & 12,58 & 13,25 & 12,80 & 12,79 & \\
\hline & 17 & 10,00 & 12,05 & 13,00 & 12,45 & 12,71 & \\
\hline Means & & 11,60 & 12,59 & 13,17 & 12,79 & 12,78 & 12,58 \\
\hline
\end{tabular}


TABLE 2. Moisture at the beginning and at the end of drying, drying speed and duration of drying of grain sorghum seeds submitted to three drying methods.

\begin{tabular}{ccccc}
\hline $\begin{array}{c}\text { Drying } \\
\text { method }\end{array}$ & \multicolumn{2}{c}{ Moisture $(\%)$} & Drying duration $(\mathrm{h})$ & Drying speed $\left(\mathrm{pph}^{-1}\right)$ \\
Natural & Beginning & End & 56 & \\
Intermittent & 18,9 & 12,6 & 4 & 0,11 \\
Stationary & 17,3 & 12,3 & 9 & 1,25 \\
\hline
\end{tabular}

TABLE 3. Monitoring air and seed mass temperatures, moisture content of seeds and relative humidity in sorghum seeds submitted to the intermittent method.

\begin{tabular}{ccccc}
\hline $\begin{array}{c}\text { Drying } \\
\text { Duration } \\
\text { (hours) }\end{array}$ & $\begin{array}{c}\text { Air temperature } \\
\left({ }^{\circ} \mathrm{C}\right)\end{array}$ & $\begin{array}{c}\text { Seed mass } \\
\text { temperature } \\
\left({ }^{\circ} \mathrm{C}\right)\end{array}$ & $\begin{array}{c}\text { Seed moisture content }{ }^{2} \\
(\%)\end{array}$ & $\begin{array}{c}\text { Relative humidity of air } \\
(\%)\end{array}$ \\
\hline 0 & 22,0 & 22,0 & 17,3 & 66,1 \\
1 & 50,3 & 38,7 & 15,7 & 43,4 \\
2 & 55,5 & 40,8 & 14,8 & 40,3 \\
3 & 55,7 & 40,6 & 13,6 & 40,2 \\
4 & 60,3 & 43,9 & 12,3 & 41,7 \\
\hline
\end{tabular}

${ }^{1}$ Equalization chamber; ${ }^{2}$ Manual meter

TABLE 4. Monitoring air and seed temperatures, seeds moisture content, and relative humidity of drying air during the stationary drying method (LPG).

\begin{tabular}{|c|c|c|c|c|c|c|c|c|c|c|}
\hline \multirow{2}{*}{$\begin{array}{l}\text { Drying } \\
\text { duration }\end{array}$} & \multirow{2}{*}{$\begin{array}{c}\text { Drying air } \\
\text { temperature }\left({ }^{\circ} \mathrm{C}\right)\end{array}$} & \multicolumn{4}{|c|}{ Seed temperatures $\left({ }^{\circ} \mathrm{C}\right)$} & \multicolumn{4}{|c|}{ Seed moisture content $(\%)$} & \multirow[t]{2}{*}{ Drying air r.h. $(\%)$} \\
\hline & & (a) & (b) & (c) & $(\mathrm{x})$ & (a) & (b) & (c) & & \\
\hline 0 & 25,0 & 25,0 & 25,1 & 25,1 & 25,0 & 18,2 & 18,2 & 18,2 & 18,2 & 55,0 \\
\hline $1 *$ & 50,4 & 38,8 & 33,8 & 31,2 & 34,6 & 16,1 & 17,7 & 17,7 & 17,1 & 23,5 \\
\hline $2 *$ & 50,2 & 47,9 & 41,8 & 34,5 & 41,4 & 14,7 & 17,0 & 17,3 & 16,3 & 22,5 \\
\hline $3 *$ & 55,3 & 49,7 & 47,6 & 40,9 & 46,0 & 12,3 & 16,4 & 16,7 & 15,1 & 18,5 \\
\hline $4 *$ & 54,3 & 51,2 & 47,4 & 43,2 & 47,2 & 12,4 & 14,8 & 16,5 & 14,5 & 18,5 \\
\hline $5^{*}$ & 55,3 & 50,3 & 47,4 & 43,7 & 47,1 & 11,6 & 14,4 & 16,2 & 14,0 & 18,5 \\
\hline $6 * *$ & 20,1 & 47,1 & 39,8 & 38,1 & 41,6 & 11,8 & 14.3 & 15,5 & 13,8 & 35,5 \\
\hline $7 * *$ & 20,3 & 41,0 & 35,6 & 29,9 & 35,5 & 12,1 & 13,8 & 15,3 & 13,7 & 70,6 \\
\hline $8 * *$ & 20,7 & 33,3 & 25,8 & 24,1 & 27,7 & 12,2 & 13,5 & 14,8 & 13,5 & 69,0 \\
\hline $9 * *$ & 20,3 & 25,8 & 23,7 & 23,1 & 24,2 & 12,3 & 13,2 & 13,8 & 13,1 & 67,5 \\
\hline $10 * * *$ & 20,4 & 22,2 & 22,5 & 22,7 & 22,4 & 12,3 & 13,0 & 13,2 & 12,8 & 68,4 \\
\hline $11 * * *$ & 20,6 & 20,3 & 21,7 & 21,9 & 21,3 & 12,5 & 13,0 & 13,1 & 12,8 & 67,9 \\
\hline
\end{tabular}

$a=$ Layer with dried seeds

$\mathrm{b}=$ Transition layer

$\mathrm{c}=$ Layer with humid seeds

$\mathrm{x}=$ Layer mean temperature or moisture

* drying

** Cooling and homogenization with ventilation

*** Cooling and homogenization without ventilation 
TABLE 5. Moisture content, purity, germination, first count and weight of a thousand seeds (WTS) results of grain sorghum seeds submitted to three drying methods.

\begin{tabular}{cccccc}
\hline $\begin{array}{c}\text { Drying } \\
\text { method }\end{array}$ & Moisture (\%) & Purity (\%) & Germination (\%) & First count (\%) & WTS (g) \\
\hline Natural & $12,2 \mathrm{a}$ & $99,5 \mathrm{a}$ & $84,4 \mathrm{~b}$ & $81,2 \mathrm{~b}$ & $25,3 \mathrm{~b}$ \\
Intermittent & $11,8 \mathrm{a}$ & $99,5 \mathrm{a}$ & $86,8 \mathrm{a}$ & $84,6 \mathrm{a}$ & $26,5 \mathrm{a}$ \\
Stationary & $11,9 \mathrm{a}$ & $99,5 \mathrm{a}$ & $84,1 \mathrm{~b}$ & $80,4 \mathrm{~b}$ & $24,2 \mathrm{c}$ \\
\hline
\end{tabular}

Means followed by the same letter in one column indicate values that do not differ statistically (Duncan test; $\mathrm{P}<0.05$ ).

The natural drying method resulted in seed germination and vigor values lower than those observed when the drying method was the intermittent one (Table 5). In natural drying, the factors that may have led to reductions in germination are thought to be more closely related to the method itself and to the influence of weather conditions. Apart from these, other aspects may have influenced the results, such as: a) the low air flow (controlled by air speed), b) the low heating power of the source, c) the dissipation of the caloric energy distributed across the system, which probably reduced drying efficiency, and d) the low drying speed may have maintained the respiration rate at high levels. This takes up energy reserves, and partly affects germination and vigor, due to the fact that bound water remains for longer periods inside the seed, which in turn produces gases and vapor in the intergranular space. Periodic upturning of seeds helped tone the situation down, as it homogenizes seeds and increases the time seeds are exposed to the drying conditions. In spite of its limitations, natural drying is still widely adopted in agriculture for being cheaper, directly or indirectly, specially for smaller seed volumes, as pointed out by Naum (2004). In the state of Rio Grande do Sul, natural drying is extensively chosen to dry seeds of forage species, such as rye grass (Maia, 1995), specially in times and places affected by sudden rains. Due to the low local heat capacity $\left(375.22 \mathrm{cal} . \mathrm{cm}^{-2}\right.$.day $\left.{ }^{-1}\right)$ and to the low drying speed under the natural drying conditions, seeds were not submitted to very high temperatures. So, seeds apparently did not suffer any physical damage, though the drying method imposed a reasonable reduction in germination rate and in vigor (physiological aspect) (Table 5). Apart from this, the method is inadequate due to the psychrometric conditions of the air, which lead to longer drying times, as observed in the present study.

The intermittent drying method resulted in seeds of higher germination and vigor (Table 5). This is explained by several factors, such as: a) the conduction of a pre cleaning stage which consisted in the elimination of large sized inert material and this resulted in a seed moisture drop of $1 \mathrm{pp}$, b) the high drying air flow, which afforded higher moisture removal rates, c) lowest exposure time of seeds to air temperature in the drying chamber, d) good synchronicity between drying time and equalization, which increases drying speed, and e) seed upturn. As this method was designed to eliminate part of the heat used together with the moisture and to release it out of the system, the physiological quality of seeds was not really diminished, as seeds are dried in a series of short drying times interrupted by longer resting times.

In terms of germination and vigor, the performance of the stationary drying method was worse than that of the intermittent one, although it did not differ from the natural drying (Table 5). Some factors may have contributed to this result, such as: the absence of initial pre-cleaning; the difficulty to remove moisture from the farthest layers (b and c), even at top air flow, due to the static pressure and to the characteristics of the sorghum seeds; seed mass remained exposed to drying air for too long, which led to overdrying of the (a) and (b) layers thus resulting in lower germination rates and vigor. The low vigor value of these seeds may be explained by the relationship between exposure time, temperature, thickness of layers, and seed structure, all of which are aspects that led to losses in seed quality due to injury. The interaction of these several factors contributed to the unevenness observed in drying speed inside the seed mass, which affected physiological quality and determined lower germination rate and lessened germination of seeds (first count). Specially in the (a) and (b) layers, the seed mass temperatures maintained above $43{ }^{\circ} \mathrm{C}$ for $4 \mathrm{~h}$ have probably reduced the quality (impaired germination and vigor). This finding confirms that it is not advisable to use values above those recommended by research, though the germination test did in fact produce satisfactory results.

The analysis of variance for the weight of 1000 seeds revealed statistically significant differences $(\mathrm{P}<0.05)$ between drying procedures. Natural drying of seeds resulted in lower weight, as compared to intermittent drying, but higher as compared to stationary drying (Table 5). The low weight of 
seeds following stationary drying may be ascribed to the fact that in this method seeds were more exposed to the flow or drying air which led to overdrying and, as a result, to a higher energy expenditure of the seed, seen in the uptake of energy reserves (Maia, 1995). Conversely, in the intermittent drying, the higher weights observed are related to the intermittence ratio, that is, the shorter exposure time in the drier coupled to the longer equalization time.

Yet, the improved technical efficiency observed in the three drying methods is related to practical issues and availability of use, to the adaptation of the method to the drying process, and to the compatibility in terms of industrial automation, as reported by Millman (2002).

Considering the importance of seed drying, alternative drying methods should be the object of constant research. For instance, the combination of the methods discussed, and the replacement of expensive fuels by cheaper alternatives to decrease environmental degradation, as well as improvements in the existing systems. These improvements are expected to increase drying speed, reduction of drying costs and a more efficient conservation of environment resources.

Seed drying is a complex subject, and very often drying available facilities are those made possible by the circumstances, not the ideal ones. In many cases, drying methods are conducted outside the specifications defined, so that the seed treatment unit as a whole may maximize performance, at minimal losses.

\section{CONCLUSIONS}

The use of intermittent dryer method to dry sorghum seeds has afforded higher moisture removal in a shorter period of time, and resulted in seeds of higher germination and vigor.

The low drying speed of sorghum seeds as observed in natural drying is influenced by the limitations imposed by the method, which led to slow desorption and determined a very long drying curve, contributing to lower seeds physiological quality.

The used layer thickness, exposure time, and the air flow in the stationary dryer affect negatively the physiological quality of sorghum seeds, as compared to the intermittent method.

\section{REFERENCES}

AHRENS, D.C.; VILLELA, F.A.; DONI FILHO, L. Qualidade fisiológica e industrial de sementes de aveia- branca (Avena sativa) na secagem intermitente. Revista Brasileira de Sementes, Brasília, v.22, n.2, p.12-20, 2000.

BERTI, M.; AHRENS, D.C.; BEUSSO, D.R. Secagem estacionária de sementes de trigo com utilização de gás liquefeito de petróleo. Revista Brasileira de Sementes, Brasília, v.27, n.2, p.81-86, 2005.

BRASIL. Ministério da Agricultura e Reforma Agrária. Regras para Análise de Sementes. Brasília,1992. 365p.

BROOKER, D.B.; BAKER-AKRKEMA, F.W.; HALL C.W. Drying cereal grains. Connecticut: The AVI publishing, 1981. 265p.

CARVALHO, N.M. A Secagem de Sementes. Jaboticabal: FUNEP, 1994. 165p.

CAVARINI, C.; SILVA, W.R.; MIRANDA, L.C.; NAKAGAWA, J.; BELGIORNO, D.C. Secagem estacionária de sementes de milho com distribuição radial do fluxo de ar. I-Qualidade fisiológica de sementes. Revista Brasileira de sementes, v. 20, n.2, p.433-440, 1998.

CONAB. Indicadores da Agropecuária. Brasília: Conab, 2004.

EMBRAPA. Plano Diretor da Embrapa Milho e Sorgo 2004-2007. Sete Lagoas, MG: CNPMS, 2005. 27p.

MAIA, M. de S. Secagem de sementes de azevém anual (Lolium multiflorum Lam.) com ar ambiente forçado. 1995.108f. Tese (Doutorado em Agronomia- Tecnologia de Sementes)-Faculdade de Agronomia Eliseu Maciel, Universidade Federal de Pelotas, Pelotas, RS, 1995.

MANTOVANI, E.C. Plantio e colheita de sorgo. Sete Lagoas, MG: CNPMS, 2003. 5p. (Comunicado técnico, 75).

MILLMAN, M.J. Equipamentos para pré-processamento de grãos. Pelotas, RS: Universitária, 2002. 205p.

MORAES, M.L.B de. Comportamento da pressão estática e da frente de secagem em uma coluna de sementes de arroz. 2000. 50f. Tese (Doutorado em Ciência e Tecnologia de Sementes) -UFPel.

NAUM, F. Energia solar: princípios e aplicações. Recife, PE: Universidade Federal Rural de Pernambuco, 2004. 32p.

TEIXEIRA, M.M; SINICIO, R.; QUEIROZ, D.M. de. Secagem de Grãos. Viçosa: Universidade Federal de Viçosa, MG: Centreinar, 1980. 61p. 